\title{
Integration of Innovative Technology 'Narmada Nidhi' in Backyard Poultry Farming for Empowering Tribal Women Self-Help Groups
}

\author{
Jitendra Singh Yadav ${ }^{1}$, Ruchi Singh ${ }^{2}$ and MK Mandal ${ }^{2}$ \\ ${ }^{1}$ College of Veterinary Science \& Animal Husbandry, NDVSU, India \\ ${ }^{2}$ Department of Veterinary and Animal Husbandry Extension, India
}

Submission: September 23, 2017; Published: October 17, 2017

*Corresponding author: Ruchi Singh, Department of Veterinary and Animal Husbandry Extension, Email: drruchivet@gmail.com

\begin{abstract}
The present study was conducted in six villages of Narayanganj and Niwas blocks of Mandla District. Data were collected through a structured interview schedule by personal interview method. For integration of Narmada Nidhi among tribal women SHGs extension interventions like awareness camps, exposure visits and trainings on poultry management were organized in the study areas. After proper extension interventions, 06 self- help-groups were formed and each group was provided with 50 Narmada Nidhi chickens to empower them. The study data revealed that, extension interventions lead to improvement in knowledge and attitude change among the members of SHGs. The each tribal SHGs were economically benefitted as they received an average income of Rs.17,032 during the 8 months study period. Proper extension strategies like awareness campaigns, exposure visits and training helps in capacity building of tribal people. Thus, appropriate extension cum technological interventions(Narmada Nidhi Backyard poultry) is play an important role to empower tribal women socially and economically, as it generates cash income and provides employment opportunities, while increasing production of valuable foods (eggs and meat) that improve household nutrition. Can empower the tribal SHGs members socially and economically through backyard poultry farming.
\end{abstract}

Keywords: Narmada Nidhi; Backyard; Poultry; Self-help group

\section{Introduction}

Recently, the women Self-Help Group (SHG) movement has gathered momentum as a powerful instrument for socioeconomic transformation of poor women in India. SHG approach is a silent revolution promoting women development and empowerment. As a nation, India is committed to the empowerment of women. The National Commission for Women [1] opined that any appraisal of women's economic contribution to be meaningful, must take into account the socio-economic status of different categories of farmers.

Backyard poultry farming (BYPF) is an important venture and integral part of mixed farming in most of the tribal villages of Mandla District of Madhya Pradesh. At the same time, it provides an excellent opportunity for gainful employment to idle or unemployed members of tribal communities. It is an important activity to empower tribal women socially and economically, as it generates cash income and provides employment opportunities, while increasing production of valuable foods (eggs and meat) that improve household nutrition. However, operational constraints such as non-availability of suitable germ-plasm, inputs, lack of scientific knowledge about rearing and diseases control limit the adoption of BYPF as an entrepreneurial activity among resource poor tribal women [2].

Thus, to improve the livelihood of tribal peoples a more holistic and self-reliant SHG approach is necessary not only in terms of improvement of income, employment and nutritional status but also in terms of community development and gender empowerment. The organized BYPF will provide an avenue for resource-poor tribal people to increase production, improve their livelihoods, reduce malnutrition, and thereby, contribute to the goal of overall poverty alleviation. The purpose to establish small-scale, self-sustainable BYP unit among women SHG is to provide a small but steady income to the household nutrition. In view of the above, the present study was undertaken to assess the empowerment of tribal women SHG through integration of Narmada Nidhi chickens in tribal areas. 


\section{Materials and Methods}

\section{Locale of the study}

The present study was conducted in Narayanganj and Niwas blocks of Mandla District of Madhya Pradesh as these two blocks have a sizeable proportion of tribal population. Three villages were selected randomly from each block (i.e. Narayanganj and Niwas) for the present study. Regarding selection of respondents, initially, an exhaustive list of tribal poultry owners was prepared from the selected villages where backyard poultry farming is being practiced. Then from each village 06 SHGs $(10$ members in each) were formed for integration of Narmada Nidhi chickens for backyard poultry farming. The following extension interventions were implemented in all the six selected villages of the study areas.

1. Organized Awareness camps: Six awareness camps were organized to aware the tribal people regarding importance of poultry farming system to improve their livelihood.

2. Organized tribal women's exposure visits: Two exposure visits of tribal poultry owners were organized at All India Co-ordinate Research Project on Poultry Breeding, Nanaji Deshmukh Veterinary Science University, Jabalpur.

3. Identification and formation of tribal women SHGs: After organizing the awareness campaigns and exposure visits one women SHG (10 tribal women) was formed from each village. Thus, the total number of SHGs and members were 06 and 60 , respectively.

4. Training/ Capacity building of tribal women SHGs: Two training programmed (3 days) to the poultry SHGs members were organized at All India Co-ordinate Research Project on Poultry Breeding, NanajiDeshmukh Veterinary Science University, Jabalpur and village level to improve the knowledge and skills of the member of SHGs.

\section{Results and Discussion}

The socio-empowerment of women SHGs was measured under the following parameters.

\section{Technology dissemination and adoption}

Distribution of Jabalpur colored birds (Narmada Nidhi): The Centre of All India Co-ordinated Research Project on Poultry Breeding, Nanaji Deshmukh Veterinary Science University, and Jabalpur has developed a Narmada Nidhi birds and has all the attributes of village poultry in terms of colour, hardiness and ability to thrive in scavenging conditions without any major changes in traditional backyard poultry farming system. This improved variety of 50 Jabalpur colored birds (10 cocks +40 hens) was distributed to each SHG. The initial average age and body weight of the birds at the time of distribution was 8 weeks and 650gm (cock) and 550gm (hen), respectively. All the birds were vaccinated against poultry diseases.
Economic empowerment: The economic empowerment of tribal women SHGs were measured by economic analysis of 50 Jabalpur colored birds (10 cock +40 hens) up to the study period ( 8 months) under the supervision of each SHG. The data presented reveals that the Radha Krishna SHG, Sankar SHG, Shree Ram SHG, Jai Ma Laxmi SHG, Anttar SHG and Vinayak SHG received an income of Rs.16261, Rs.17554, Rs. 18201, Rs.17398, Rs.17201 and Rs. 15577, respectively during the study period. The overall economic analysis was also measured and presented in Table 1 . The Table 1 clearly indicates that on an average each SHG received an income of Rs.17032 (each member-1703.2) through improved backyard poultry farming.

Table 1: Overall economic analysis of self-help groups.

\begin{tabular}{|c|c|}
\hline Particulars & Cost (Rs.) \\
\hline \multicolumn{2}{|c|}{ (A) Expenditure } \\
\hline $\begin{array}{l}\text { i. Cost of pullet and cockrel (8 } \\
\text { wks.) }\end{array}$ & 24,000 \\
\hline ii. Cost of medicines & 1,500 \\
\hline iii. Cost of feed & 5,400 \\
\hline iv. Miscellaneous cost & 600 \\
\hline Total expenditure & 31,500 \\
\hline \multicolumn{2}{|c|}{ (B) Return } \\
\hline i. Sale of cocks* & 6560 \\
\hline ii. Present value of cocks & 18605 \\
\hline $\begin{array}{l}\text { iii. Consumed and sale of eggs ( } \\
\text { upto } 8 \text { months) }\end{array}$ & 34811 \\
\hline iv. Present value of hens* & 73716 \\
\hline Gross return & 133692 \\
\hline Total profit ( B-A) & 102192 \\
\hline Average profit/SHG & 17032 \\
\hline
\end{tabular}

Nutritional Security: Consumption of eggs and chicken has gone up with farmers possessing improved colored Narmada Nidhi birds. The frequencies of consumption of the eggs, particularly in children are increased. Egg became an instant food available to farmers particularly in the morning just before a child's left to school. It has enhanced protein consumption in daily diet of a farm family.

Low cost of feeding and management: Backyard poultry thrives on kitchen waste, broken waste grains, insects, ants and worms also backyard organic waste. There is no special management required for rearing. It can be done in morning and evening time by doing another major work.

Social/Gender empowerment: Regarding social/ gender impact, it was observed that tribal society is male dominated where low or no money remains in hands of farm women's. Therefore, with the help of backyard poultry with Narmada Nidhi income of tribal women were increased and all these amounts are in hands of farm women's. So they became a money holder person of a family and because of that she is a major family member having the role of decision making. 


\section{Conclusion}

The study shows that the enterprises like poultry farming have considerable potential as sustainable income generating activities for the tribal women in SHG. The group based approach enables the members to accumulate capital by way of small saving and get access to formal credit facilities. Suitable extension interventions (awareness campaigns, exposure visits, trainings) can empower the tribal women in terms of their knowledge, skill and attitude. The study also emphasis that to improve the livelihood of tribal peoples. Further, SHG approach is necessary not only in terms of improvement of income, employment and nutritional status but also in terms of community development and gender empowerment. The BYPF through improved variety provides an avenue for resource-poor tribal people to increase production, improve their livelihoods, reduce malnutrition, and thereby, contribute to the goal of overall poverty alleviation.

\section{References}

1. National Commission for Women (2011).

2. Mandal MK, Khandekar N, Khandekar P (2006) Backyard poultry farming in Bareilly district of Uttar Pradesh, India. Livestock Research for Rural Development 18(7): 45-67.

\section{Your next submission with Juniper Publishers will reach you the below assets}

- Quality Editorial service

- Swift Peer Review

- Reprints availability

- E-prints Service

- Manuscript Podcast for convenient understanding

- Global attainment for your research

- Manuscript accessibility in different formats ( Pdf, E-pub, Full Text, Audio)

- Unceasing customer service

Track the below URL for one-step submission https://juniperpublishers.com/online-submission.php 
